\title{
Energy flows in lowland soybean production system in Brazil
}

\author{
Fluxos de energia em sistema de produção de soja em várzea no Brasil
}

\author{
Maria Carolina da Silva Andrea ${ }^{\mathrm{I}}$ Thiago Libório Romanelli ${ }^{\mathrm{I}^{*}}$ José Paulo Molin $^{\mathrm{II}}$
}

\section{ABSTRACT}

Soybean is the main product of Brazilian agribusiness, both production and income. Considering the increase in food and energy demand and the search for more sustainable production systems, this study aimed to analyze inputs and energy use of a possible area of expansion of soybean production: a system under sub irrigation management located in a lowland area of Cerrado biome, northern region of Brazil. Its environmental performance was compared to other Brazilian locations among them traditionally soybean producers. The evaluation and comparison was made through material and energy flow tools in order to determine the inputs embodied per area, as well as energy demand, availability and efficiency in the analyzed production system. Energy demand (IE) and energy availability $(O E)$ of the analyzed production system were

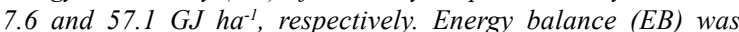
49,5 GJ ha ${ }^{-1}$, energy return over investment (EROI) was 7.5 and embodied energy in grains (EE) was 2,2 $\mathrm{MJ} \mathrm{kg-1}^{-1}$, respectively. Highest energy consumption was due to the use of fertilizers, fuel and herbicide. The system is energy efficient, since it provides more energy than demands, and efficient when compared to usual production systems in other regions, however it is highly dependent on non-renewable energy.

Key words: Glycine max (L.) Merr, material flow, energy balance, EROI.

\section{RESUMO}

A soja é o principal produto do agronegócio Brasileiro, em volume e geração de renda. Considerando o aumento da demanda por alimentos e energia, bem como a busca por sistemas de produção mais sustentáveis, o presente estudo teve como objetivo analisar o uso de energia oriunda de insumos agrícolas em área de possível expansão de produção de soja: sistema de produção sob subirrigação em área de várzea no Cerrado, região Norte do Brasil. Seu desempenho ambiental foi comparado a outros locais no Brasil, entre os quais regiões tradicionalmente produtores de soja. A avaliação e comparação foram feitas por meio do uso de ferramentas de fluxo de materiais e energia, a fim de determinar a quantidade de insumos utilizados por área, bem como a demanda, disponibilidade e eficiencia do uso de energia no sistema de produção avaliado. A demanda (IE) e disponibilidade (OE) de energia foram de 7.6 e $57.1 \mathrm{GJ} \mathrm{ha}^{-1}$, respectivamente. O balanço energético $(B E)$, o retorno de energia sobre o investimento (EROI) e a energia incorporada dos grãos (EE) foram $49.5 \mathrm{GJ} \mathrm{ha}^{-1}, 7.5$ e $2.2 \mathrm{MJ} \mathrm{kg}^{-1}$, respectivamente. O maior consumo de energia foi devido à utilização de fertilizantes, herbicidas e combustivel. O sistema analisado é eficiente no uso da energia, uma vez que fornece mais energia do que é demandado, e eficiente quando comparado a sistemas de produção usuais em outras regiões, embora seja altamente dependente de energia de origem não-renovável.

Palavras-chave: Glycine Max (L.) Merr, fluxo de materiais, balanço energético, EROI.

\section{INTRODUCTION}

Brazil is the third world producer of Soybean (Glycine max (L.) Merr) (71 million tons in 2012) behind US and China (FAO, 2014). In 2014, its cultivated area represented $41 \%$ of total arable area and the highest value among other crops in the country, with national average yield of $2.8 \mathrm{t} \mathrm{ha}^{-1}$. The crop is mainly cultivated in the South-Central region ( $81 \%$ of the crop cultivated area and $82 \%$ of total

IPrograma de Pós-graduação em Engenharia de Sistemas Agrícolas, Escola Superior de Agricultura "Luiz de Queiroz" (ESALQ), Piracicaba, SP, Brasil.

IDepartamento de Engenharia de Biossistemas, Escola Superior de Agricultura "Luiz de Queiroz" (ESALQ), 13418-900, Piracicaba, SP, Brasil. E-mail: romanelli@usp.br. "Corresponding author. 
production) over the Northern region (4\% either in cultivated area or total production). Northern and Midwest regions were the only ones that showed increase in yields above the national average. Within northern region, Tocantins state (TO) stands out in soybean production: $61 \%$ of crop cultivated area, $60 \%$ of total production, and yields higher than the national average (IBGE, 2014). Soybean is the main responsible crop for the agricultural expansion in the Cerrado (Brazilian savannah). The biome ( $2^{\text {nd }}$ largest in Brazil, occupying $22 \%$ of its area), comprises important springs, such as the Araguaia-Tocantins basin and diverse landscape, such as lowland areas. These lowland areas undergo periodic flooding periods at the rainy season (October to March), and present high humidity and water accumulation in most part of the year (EMBRAPA, 1999). Soybean cultivation has been expanding in those areas in the dry season (May to September), usually in a system with a crop with great demand for water and flooded soil on the humid season (e.g. rice). In that period, the legume crop finds good soil drainage, allowing its root development. These areas also enables the use of sub irrigation systems, employed to manage the groundwater elevation (PELÚZIO et al. 2008), aiming to keep the soil around $70 \%$ of field capacity.

In the last decades, agriculture has been presenting an increase of average yields simultaneously to an increasing use of energy through inputs use (EPE, 2014), which are generally obtained by using fossil energy sources. Use of fossil energy sources is related to environmental impacts (depletion of oil reserves, emission of greenhouse gases), but environmental policies that target only the reduction of their use may adversely affect the economy (CARVALHO et al. 2015). Environmental assessment may be added to the economical perspective and contribute to a broader analysis in terms of managing the sustainability of a production system. Material flow analysis, a tool that enables the determination of used inputs in a system (ROMANELLI \& MILAN, 2010b) can be used as basis for economic and/ or energy flow analysis, assigning the amount of resources (energy, economic) demanded by a system to produce a good service (FRANZESE et al. 2009). Studies such as ROMANELLI et al. (2012) used such tools in order to compare use of inputs and energy in soybean production systems in different states. Considering the increasing importance of soybean crop in lowland areas in Northern region and the lack of studies presenting environmental assessments complementing management decisions in crop production, the objectives of this study were:
i.Determine the demand, availability and efficiency of energy through inputs use in a lowland soybean production system and ii.Compare the energy use of the analyzed system with other soybean production systems in Brazil.

\section{MATERIALS AND METHODS}

Primary data for the soybean production in Tocantins was surveyed by ZAMBRZYCKI (2012), from May to September 2011, in a 609-ha area, in the district of "Lagoa da Confusão" (49³7'56" W and $10^{\circ} 47^{\prime} 50^{*} \mathrm{~S}, 178 \mathrm{~m}$ a. s. 1.) Climate (C2wA'a') is humid and semi-humid (Köppen) with precipitation varying between 1500 to $2000 \mathrm{~mm}$ (November May), and absence of rain (June - October) within a year. The soil is classified in its major part as Gleysol (EMBRAPA, 1999) and the area has been used for crop succession (rice and soybean) for the last five years, supplied by Formoso river basin. Data from ROMANELLI et al. (2012), representing usual GMO (Genetically Modified Organism) soybean production systems in Brazilian states, was used for comparison of production systems. Inputs were classified according to ROMANELLI \& MILAN (2010b). Labor was not considered since its energy embodiment is usually very low in comparison with the other inputs (ROMANELLI et al. 2012). Quantification of inputs used comprised the material flow (MF) for each input of the systems (Table 1). Association of material flow with energy indexes (EI) of each input (Table 1), provided the systems energy flow (Eqs 1 to 4 ) and the determination of indicators of energy use (Eqs 5 to 9).

EF d= MFi $x$ Eii

Where EFd is the energy flow from directly applied inputs ( $\left.\mathrm{MJ} \mathrm{ha}^{-1}\right)$, MFi is the material flow of the applied inputs (unit ha-1) and Ei is the energy index of inputs (MJ unit $\left.{ }^{-1}\right)$.

$\mathrm{EFf}=\mathrm{MFi} \times \mathrm{Ei}$

Where EFf is the energy flow from fuel use $\left(\mathrm{MJ} \mathrm{ha}^{-1}\right)$. To provide the volume of fuel consumed, the tractor fuel tank was completed before the beginning of the operation, and after finished, the tractor fuel tank was completely full again. The area in which it worked was known since every plot had the area previously determined.

EFmd $=$ MFi $\times$ Ei $/$ UL $\times$ OFC

Where EFmd is Energy flow from machinery depreciation, $\left(\mathrm{MJ} \mathrm{ha}^{-1}\right)$, UL is the useful life of the equipments (h), OFC is the operational field capacity, $\left(\mathrm{ha} \mathrm{h}^{-1}\right.$ ) (ROMANELLI \& MILAN, 2010b). EFir $=$ MFi x EIi / Air

Ciência Rural, v.46, n.8, ago, 2016. 
Table 1 - Energy index (EI) and material flow (MF) of inputs used in soybean systems.

\begin{tabular}{|c|c|c|c|c|c|c|c|c|c|c|c|}
\hline \multirow[t]{2}{*}{ Inputs (Unit) } & \multirow[t]{2}{*}{$\begin{array}{l}\text { EI MJ } \\
\text { unit }^{-1}\end{array}$} & \multirow{2}{*}{$\begin{array}{l}\text { This Study } \\
\text { TO }\end{array}$} & \multicolumn{9}{|c|}{$\begin{array}{l}\text {-MF (Unit ha }{ }^{-1} \text { )- } \\
\text { ROMANELLI e }\end{array}$} \\
\hline & & & RS & MS & $\mathrm{GO}$ & PR & MT & BA & MG & MA & SP \\
\hline${ }^{1} \operatorname{Diesel}(\mathrm{L})$ & 37.8 & 44.1 & 40.1 & 43.4 & 50.2 & 50.5 & 41.7 & 38.6 & 42.3 & 42.2 & 32.3 \\
\hline $\begin{array}{l}{ }^{2} \text { Machinery } \\
\text { depreciation }(\mathrm{kg})\end{array}$ & 68.9 & 3.7 & 5.1 & 5.6 & 5.8 & 4.9 & 4.9 & 4.8 & 4.8 & 4.0 & 4.6 \\
\hline${ }^{3}$ Limestone (kg) & 1.67 & 0.0 & 250.0 & 250.0 & 560.0 & 200.0 & 560.0 & 560.0 & 560.0 & 560.0 & 500.0 \\
\hline${ }^{4} \mathrm{~N}(\mathrm{~kg})$ & 74 & 0.0 & 0.0 & 0.0 & 0.0 & 0.0 & 0.0 & 0.0 & 8.0 & 8.0 & 5.0 \\
\hline${ }^{5} \mathrm{P}_{2} \mathrm{O}_{5}(\mathrm{~kg})$ & 12.6 & 54.0 & 50.0 & 48.0 & 72.0 & 48.0 & 64.0 & 64.0 & 80.0 & 80.0 & 50.0 \\
\hline${ }^{5} \mathrm{~K}_{2} \mathrm{O}(\mathrm{kg})$ & 6.7 & 90.0 & 50.0 & 48.0 & 54.0 & 72.0 & 64.0 & 64.0 & 80.0 & 80.0 & 50.0 \\
\hline${ }^{6}$ Seeds $(\mathrm{kg})$ & 20.4 & 54.0 & 65.0 & 70.0 & 70.0 & 65.0 & 60.0 & 65.0 & 60.0 & 65.0 & 75.0 \\
\hline${ }^{7}$ Seed treatment (L) & 0 & 1.0 & 1.0 & 1.7 & 1.0 & 1.5 & 1.7 & 2.0 & 1.2 & 2.0 & 2.2 \\
\hline${ }^{7}$ Acaricide (L) & 184.7 & 0.0 & 0.5 & 0.5 & 0.2 & 0.0 & 0.2 & 0.2 & 1.0 & 1.0 & 1.2 \\
\hline${ }^{7}$ Fungicide (L) & 97.13 & 0.7 & 1.2 & 1.1 & 1.1 & 1.1 & 1.1 & 1.1 & 1.1 & 1.2 & 1.2 \\
\hline${ }^{8}$ Herbicide (L) & 454.2 & 3.0 & 4.0 & 4.0 & 3.5 & 3.5 & 3.5 & 3.5 & 3.5 & 3.5 & 3.5 \\
\hline${ }^{7}$ Inseticide (L) & 184.7 & 3.3 & 0.6 & 0.6 & 1.0 & 2.2 & 0.6 & 0.6 & 0.6 & 0.2 & 3.5 \\
\hline${ }^{7}$ Electricity (kWh) & 11.9 & 58.1 & 0.0 & 0.0 & 0.0 & 0.0 & 0.0 & 0.0 & 0.0 & 0.0 & 0.0 \\
\hline${ }^{7}$ Yield $\left(\mathrm{t} \mathrm{ha}^{-1}\right)$ & - & 3.4 & 2.1 & 2.6 & 2.7 & 2.8 & 2.8 & 2.5 & 2.6 & 2.6 & 2.8 \\
\hline
\end{tabular}

${ }^{1}$ EPE (2014); ${ }^{2}$ ULBANERE \& FERREIRA (1989); ${ }^{3}$ FERRARO JUNIOR (1999); ${ }^{4}$ PELLIZZI (1992); ${ }^{5}$ MACEDÔNIO \& PICCHIONI (1985); ${ }^{6}$ EMBRAPA (2006); ${ }^{7}$ PIMENTEL (1980); ${ }^{8}$ FLUCK \& BAIRD (1982). For seed treatment, energy index of pesticide were accounted.

Where EFir is the energy flow from irrigation system use $\left(\mathrm{MJ} \mathrm{ha}^{-1}\right)$, Air is the irrigated area (ha).Water energy index was not accounted since it does not undergoes through industrial process.

$\mathrm{IE}=\mathrm{EF}+\mathrm{EFf}+\mathrm{EFmd}+\mathrm{EFir}$

Where IE is the input energy of the system $\left(\mathrm{MJ} \mathrm{ha}^{-1}\right)$.

$\mathrm{OE}=\mathrm{Y} \times$ Eis

Where OE is the output energy of the system $\left(\mathrm{MJ} \mathrm{ha}^{-1}\right), \mathrm{OE}$ is the output energy of the system $\left(\mathrm{MJ} \mathrm{ha}^{-1}\right), \mathrm{Y}$ is yield $\left(\mathrm{kg} \mathrm{ha}^{-1}\right)$ and Eis is soybean grain energy index $\left(\mathrm{MJ} \mathrm{kg}^{-1}\right)$.

$\mathrm{EB}=\mathrm{OE}-\mathrm{IE}$

Where EB is the energy balance of the system $\left(\mathrm{MJ} \mathrm{ha}^{-1}\right)$ (SIQUEIRA et al. 1999).

$\mathrm{EROI}=\mathrm{OE} / \mathrm{IE}$

Where EROI is the energy return over investment $\left(\mathrm{MJ} \mathrm{MJ}^{-1}\right)$ (HALL, 2004).

$\mathrm{EE}=\mathrm{IE} / \mathrm{Y}$

Where EE is the embodied energy of final product $\left(\mathrm{MJ} \mathrm{kg}^{-1}\right)$ (ROMANELLI \& RAUCCI, 2011).

\section{RESULTS}

The share (\%) of each input (Table 2$)$ in the whole systems' energy demand and the efficiency of energy use (Table 3 ) of the analyzed system and other
Brazilian locations were determined. The indirect use of energy (fuel, machinery depreciation and irrigation) among systems varied between $14 \%$ and $88 \%$, in which the highest and lowest consumption were from TO and SP systems, respectively. Highest indirect use of energy was found for TO system, due to the use of irrigation system, which represented $26 \%$ of it. Machinery depreciation was the lowest participation within the indirect use of energy for all systems, explained by the dilution of the hours of machinery use in one production cycle. Indirect use of energy was lower compared with direct energy demand for all locations. Direct use of energy (inputs applied on field) varied from $65 \%$ to $82 \%$ of total IE for TO and SP systems, respectively. This major share is mainly related to the use of herbicides, potassium and phosphorus fertilizers and seed, wherein variation on the energy demand from each input was observed. TO and SP systems presented the major share of total energy demand due to use of fertilizers and herbicides, respectively. These type of variations can be related to region-specific conditions (e.g. climate, soil, management). IE and OE varied between $1 \%$ to $20 \%$ and $18 \%$ to $38 \%$, respectively. TO system did not present the highest IE, even with the use of electricity and it did preset the highest OE. Regarding the efficiency of energy use, the highest 
Table 2 - Share of each input in total energy demand in the soybean systems.

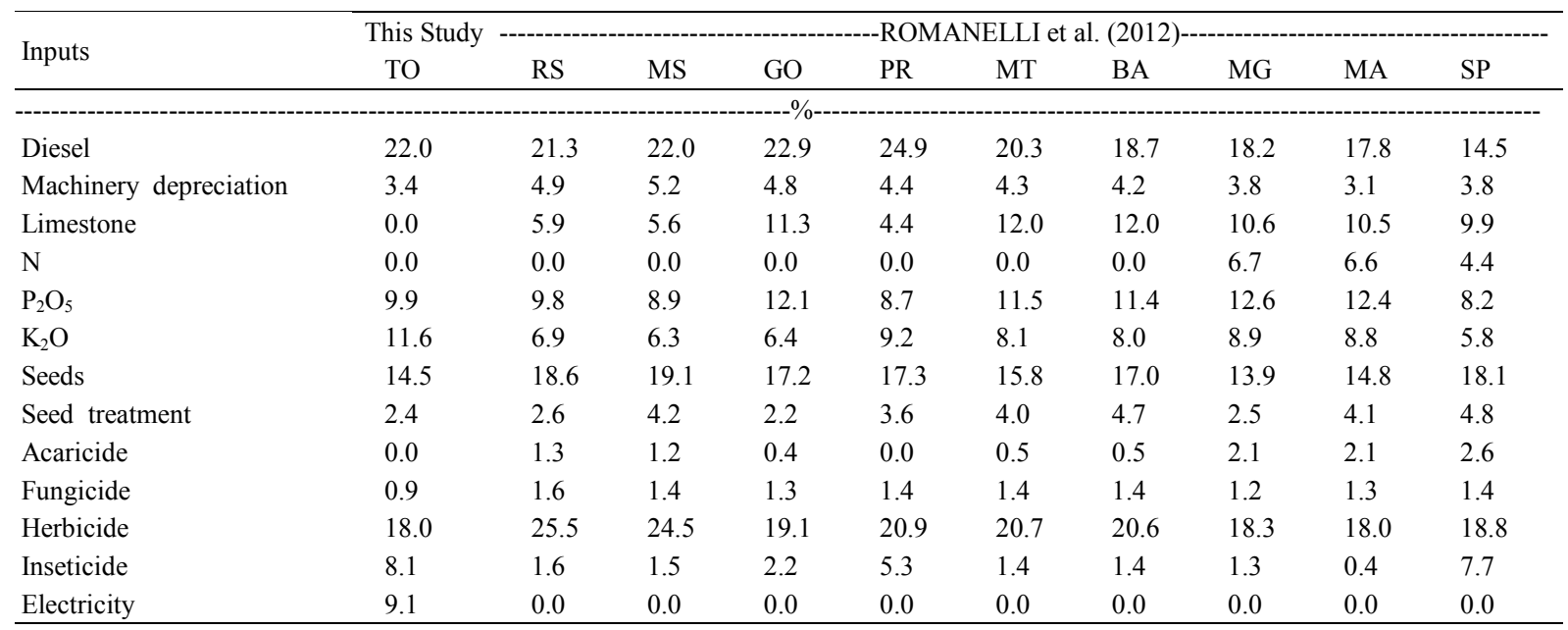

EB value was found for TO system, 20\% higher than the second highest values (PR and MT states) and $3 \%$ higher than the lowest values (RS state). More favorable EROI and EE values were also found for TO system, followed by PR and MT states, main soybean producers in the country.

\section{DISCUSSION}

In terms of share of each input in energy demand, high values for diesel use in agriculture mechanized systems is widely reported (ROMANELLI \& MILAN 2010a, RAMEDANI et al. 2011). MESQUITA et al. (1982) found 53\%, 48\% and $26 \%$ for the diesel participation in conventional, reduced, and no-tillage soybean production systems. Low or none demand for nitrogen fertilizer for soybean production is also recognized as an advantage from energy view (PELLIZZI, 1992; CAVALETT \& ORTEGA, 2010; ROMANELLI et al. 2012). Pesticides in general (seed treatment, insecticide, acaricide and fungicide), represent a high energy demand, despite the small amounts usually used (CAVALETT \& ORTEGA, 2010), due to their substantially high energy index (PIMENTEL, 1980). Seeds also represent a significant energy demand, as stated by MESQUITA et al. (1982). The authors found greater amount of energy due to soybean seed use ( $24 \%$ of the system total energy demand). The use of electricity through the irrigation in TO system most likely contributed for its higher yields. Although it did impact IE, the source of energy, predominantly renewable in Brazil (hydroelectricity) (EPE, 2014), should also be considered.

In terms of efficiency indicators, high EB values are favored by larger production volumes since it indicates the net amount of energy available per unit area. For TO system, highest OE contributed to the highest EB. The system also presented the highest EROI, indicating its efficiency, since the indicator points how many times the system can return the invested energy (SCHROLL, 1994). For $\mathrm{EE}$, a more favorable value is the lowest, since it means that the system "spent" less energy to produce one unit of mass of final product (dry grain in this study). The importance of evaluating the efficiency of energy use using more than one indicator relies on the impossibility of one indicator providing a broad conjuncture of the system. Although the TO system did not have the lowest IE probably to the use of irrigation system, it presented the most favorable values ofEB, EROI and EE, showing the compensation of demand and supply of energy on those specific conditions, resulting in the highest energy efficiency. All the regions' specificities (environmental and management) should be considered, since they will directly influence the type and amount of inputs used, and ultimately on energy demand, availability and efficiency of its use in the system.

Other studies showed the efficiency of energy use in soybean cropping systems under different conditions from the present study. SANTOS et al. 2007 determined EB and EROI when comparing tillage practices in soybean system in RS state. The 
Table 3 - Energy use indicators for the soybean systems.

\begin{tabular}{|c|c|c|c|c|c|c|c|c|c|c|c|}
\hline \multirow{2}{*}{ Indicator } & \multirow{2}{*}{ Unit } & \multirow{2}{*}{$\begin{array}{c}\text { This Study } \\
\text { TO }\end{array}$} & \multicolumn{9}{|c|}{ 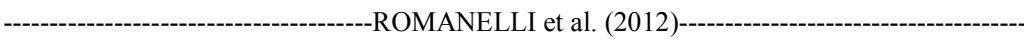 } \\
\hline & & & RS & MS & GO & PR & MT & BA & MG & MA & SP \\
\hline IE & $\mathrm{MJ} \mathrm{ha}^{-1}$ & 7.6 & 7.1 & 7.5 & 8.3 & 7.7 & 7.8 & 7.8 & 8.8 & 8.9 & 8.4 \\
\hline $\mathrm{OE}$ & $\mathrm{MJ} \mathrm{ha}^{-1}$ & 57.1 & 35.3 & 44.4 & 45.4 & 47.0 & 47.0 & 42.0 & 43.7 & 43.7 & 47.0 \\
\hline EB & $\mathrm{MJ} \mathrm{ha}^{-1}$ & 49.5 & 28.2 & 36.9 & 37.1 & 39.4 & 39.3 & 34.2 & 34.9 & 34.7 & 38.6 \\
\hline EROI & $\mathrm{MJ} \mathrm{MJ}^{-1}$ & 7.5 & 5.0 & 5.9 & 5.5 & 6.1 & 6.1 & 5.4 & 5.0 & 4.9 & 5.6 \\
\hline $\mathrm{EE}$ & $\mathrm{MJ} \mathrm{kg}^{-1}$ & 2.2 & 3.4 & 2.8 & 3.1 & 2.7 & 2.8 & 3.1 & 3.4 & 3.4 & 3.0 \\
\hline
\end{tabular}

higher values they reported (190 $\mathrm{MJ} \mathrm{ha}^{-1}$ and $72 \mathrm{MJ}$ $\mathrm{MJ}^{-1}$, respectively) when compared to the present study, refers to the sum of values of two crops in the year (soybean and a winter crop). They also considered as available energy the nitrogen content in dry matter and straw left in the field. MELO et al 2007 reported similar (5.5) EROI values in soybean production system in PR state. In Iran, for environmental conditions very different from Brazil, RAMEDANI et al. 2011 surveyed soybean production systems and determined the use and efficiency indicators, $18 \mathrm{MJ} \mathrm{ha}^{-1}, 71 \mathrm{MJ}^{-1} \mathrm{ha}^{-1}, 53 \mathrm{MJ}^{-1}$ ha 9.86 $\mathrm{MJ} \mathrm{kg}^{-1}$ and $4.62 \mathrm{MJ} \mathrm{MJ}^{-1}$ for IE, OE, EB, EE and EROI, respectively. The use of energy flows analysis has proven to be a useful tool for comparison of the impact of agricultural inputs and their energy demand on the whole system performance. The possibility of accounting for inputs not easily quantified, such as electricity and machinery, is an advantage, especially when considering a crop with high input demand such as soybean. The tools utilized also provide important information for monitoring the system environmental performance, related to the use of fossil energy sources in the production process. However, it is emphasized that energy flows analysis did not include other externalities of the process that goes beyond the use of "commercial" energy, such as pollution in watercourses water by inputs, deforestation, loss of biodiversity and others.

\section{CONCLUSION}

The evaluated soybean production on a floodplain system is energy efficient, even when compared to historically important states in Brazilian soybean production. With some variability among locations, largest energy demands were due to the use of diesel, fertilizer, seeds and herbicide. All systems provide more energy than demand. TO system was the more efficient, although they are also highly dependent on fossil and industrialized energy sources. The tools utilized are useful for analyzing the system energy performance, however local conditions should be carefully considered.

\section{REFERENCES}

CARVALHO, A. L. de et al. A hybrid input-output multi-objective model to assess economic-energy-environment trade-offs in Brazil. Energy, v. 182, p.769-785, 2015. Available from: <http://dx.doi. org/10.1016/j.energy.2015.01.089>. Accessed: Mar 10, 2015. doi: 10.1016/j.energy.2015.01.089.

CAVALETT, O.; ORTEGA, E. Integrated environmental assessment of biodiesel production from soybean in Brazil. Journal of Cleaner Production, v.18, p. 55-70, 2010. Available from: $<$ http://dx.doi.org/10.1016/j.jclepro.2009.09.008>. Accessed: Dez 8, 2014. doi: 10.1016/j.jclepro.2009.09.008

EMBRAPA. Sistema Brasileiro de Classificação de Solos. Rio de Janeiro: Embrapa Solos, 1999. 412 p.

EMBRAPA. Tecnologia de produção de soja: região central do Brasil. Londrina: Embrapa Soja, 2006. 220 p. (Sistema de Produção, 9).

EPE. Brazilian Energy Balance - Final Report - 2014 base year 2013. Available from: <https://ben.epe.gov.br/ BENRelatorioFinal.aspx ?anoColeta $=2014$ \&anoFimColeta $=201$ 3>. Accessed: Nov 15, 2014.

FERRARO JUNIOR, L.A. Proposição de método de avaliação de sistemas de produção e de sustentabilidade. 1999. $132 \mathrm{f}$. Tese (Mestrado em Fitotecnia) - Escola Superior de Agricultura "Luiz de Queiroz”, Universidade de São Paulo, Piracicaba, SP.

FAOSTAT. Food. agriculture organization of the United Nations. Statistical database. 2014. Available from: $<$ http://faostat. fao.org >. Accessed: Nov 12, 2014.

FLUCK, R.E.; BAIRD, C.D. Agriculture energetic. Westport: AVI Publishers, 1982. 192 p.

FRANZESE, P.P. et al. Sustainable biomass production: A comparison between gross energy requirement and emergy

Ciência Rural, v.46, n.8, ago, 2016. 
synthesis methods. Ecological Indicators, v.9, n.5, p. 959 970, 2009. Available from: <http://dx.doi.org/10.1016/j. ecolind.2008.11.004>. Accessed: Nov 20, 2014. doi: 10.1016/j. ecolind.2008.11.004

HALL, C.A.S. The myth of sustainability development personal reflection on energy, its relation to neoclassical economics and Stanley Jevons. Journal of Energy Resource Technology, v. 126, n. 2, p.85-89, 2004. Available from: <http:// dx.doi.org/10.1115/1.4030447>. Accessed: Fev 20, 2015. doi: $10.1115 / 1.4030447$

IBGE. Levantamento sistemático da produção agrícola 2014. Available from: <http://www.ibge.gov.br/home/estatistica/ indicadores/agropecuaria/lspa/default.shtm $>$. Accessed: Jan 10, 2015.

MACEDÔNIO, A.C.; PICCHIONI, S.A. Metodologia para o cálculo do consumo de energia fóssil no processo de produção agropecuária. v.1. Curitiba: Secretaria de Estado da Agricultura, 1985. 95p.

MELO, D. et al. Energetic balance of soybean and corn production systems in a farm of the West of Paraná, Brasil. Acta Scientiarum Agronomy, Maringá, v.29, n.2, p.173-178, 2007. Available from: $<$ http://dx.doi.org/10.4025/actasciagron.v29i2.233>. Accessed: Jan 15, 2015. doi: 10.4025/actasciagron.v29i2.233.

MESQUITA, C.M.; ROESSING, A.C.; GAZZIERO, D.L.P Consumo de energia e avaliação técnica-econômica de sistemas de produção de soja. In: SEMINÁRIO NACIONAL DE PESQUISA DE SOJA, BRASÍLIA. 1982. Anais... Londrina: EMBRAPACNPSo, 1982. Online. Available from: <http://www.bdpa.cnptia. embrapa.br/consulta/busca $? \mathrm{~b}=$ pc $\&$ id $=453747 \&$ biblioteca $=$ vazio $\&$ busca=autoria:\%22GAZZIERO,\%20D.\%22\&qFacets=autoria:\%2 2GAZZIERO,\%20D.\%22\&sort=\&paginacao=t\&paginaAtual $=8>$. Accessed: Nov 10, 2014.

PELLIZZI, G. Use of energy and labour in Italian agriculture. Journal of Agriculture Engineering Research, v.52, n.2, p.111 119, 1992. Available from: <http://dx.doi.org/10.1016/00218634(92)80054-V>. Accessed: Fev 10, 2015. doi: 10.1016/00218634(92)80054-V.

PELUZZIO, J.M. et al. Effect of the sowing season on the conduct of soybean cultivars, in Tocantins state Southern. Bioscience Journal, v. 24, n. 1, p. 75-80, 2008

PIMENTEL, D. Handbook of energy utilization in agriculture. Boca Raton: CRC Press, 1980. 475 p.

RAMEDANI, Z.; RAFIEE, S.; HEIDARI, M.D. An investigation on energy consumption and sensitivity analysis of soybean production farms. Energy, v.36, p.6340-6344, 2011. Available from: <http://dx.doi.org/10.1016/j.energy.2011.09042>. Accessed: Jan 15, 2015. doi: 10.1016/j.energy.2011.09042.

ROMANELLI, T.L.; MILAN, M. Energy performance of a production system of eucalyptus. Revista Brasileira de Engenharia Agrícola e Ambiental, v.14, n.8, p.896-903, 2010a. Available from: <http:// dx.doi.org/10.1590/S1415-43662010000800015>. Accessed: Nov 20, 2014. doi: 10.1590/S1415-43662010000800015.

ROMANELLI, T.L.; MILAN, M Material flow determination through agricultural machinery management. Scientia Agricola, Piracicaba, v. 67 , n. 4, p. 375-495, 2010b. Available from: <http:// dx.doi.org/10.1590/S0103-90162010000400001>. Accessed: Nov 15, 2014. doi: 10.1590/S0103-90162010000400001.

ROMANELLI, T.L.; NARDI, H.S.; SAAD, F. Material embodiment and energy flows as efficiency indicators of soybean (Glycine max) production in Brazil. Engenharia Agrícola, v. 32, n. 2, p. 261-279, 2012. Available from: <http://dx.doi.org/10.1590/ S0100-69162012000200006>. Accessed: Dez 12, 2014. doi: 10.1590/S0100-69162012000200006.

ROMANELLI, T.L.; RAUCCI, G.S. Biomassa de pastagens para a produção de energia. In.: PEDREIRA, C. G. S.; MOURA, J. C.; FARIA; V. P (Ed.). A empresa pecuária baseada em pastagens. Piracicaba: FEALQ, 2011. p.159-187.

SANTOS, H.P. et al. Effect of cultural practices on energy conversion and balance. Bragantia, Campinas, v.66, n.2, p.299306, 2007. Available from: <http://dx.doi.org/10.1590/S000687052007000200014>. Accessed: Jan 25, 2015. doi: 10.1590/ S0006-87052007000200014

SCHROLL, H. Energy-flow and ecological sustainability in Danish agriculture. Agriculture, Ecosystems and Environment, v. 5, p. 301-310, 1994. Available from: <http://dx.doi.org/0.1016/01678809(94)90142-2>. Accessed: Fev 15, 2015. doi: 0.1016/0167$8809(94) 90142-2$

SIQUEIRA, R. et al. Balanço de energia na implantação e manejo de plantas de cobertura do solo. Engenharia Agrícola, v.19, n.1, p.80-89, 1999

ULBANERE, R.C.; FERREIRA, W.A. Análise do balanço energético para à produção de milho no Estado de São Paulo. Engenharia Agrícola, v.4, p.35-42, 1989.

ZAMBRZYCKI, G. C. Fluxos de energia de um sistema de produção de soja no Tocantins. 2012. Dissertação (Mestrado em Máquinas Agrícolas) - Escola Superior de Agricultura Luiz de Queiroz, Universidade de São Paulo, Piracicaba, SP. 